Pengaruh Lama Penyimpanan dan Metode Pemasakan - Sari, dkk Jurnal Pangan dan Agroindustri Vol.6 No.1:17-27, Januari 2018

\title{
PENGARUH LAMA PENYIMPANAN DAN METODE PEMASAKAN TERHADAP KARAKTERISTIK FISIKOKIMIA LABU KUNING (Cucurbita moschata)
}

\section{Effects of Storage Time and Cooking Methods on Physicochemical Characteristic of Pumpkin (Cucurbita moschata)}

\author{
Nanda Puspita Sari, Widya Dwi Rukmi Putri \\ Jurusan Teknologi Hasil Pertanian, FTP Universitas Brawijaya Malang \\ Jl. Veteran, Malang 65145 \\ *Penulis Korespondensi, email: nandapuspitasari17@gmail.com
}

\begin{abstract}
ABSTRAK
Ukuran labu kuning (Cucurbita moschata) yang besar menjadi kendala dalam pemanfaatan skala rumah tangga karena tidak bisa diolah sekaligus. Proses pemasakan yang tidak tepat dapat mengubah karakteristik labu kuning tersebut. Penelitian ini bertujuan untuk mengetahui perubahan karakteristik fisik dan kimia labu kuning potong pada metode pemasakan yang berbeda setelah dilakukan penyimpanan. Penelitian ini menggunakan Rancangan Acak Kelompok (RAK) dua faktor yaitu lama penyimpanan yang terdiri 3 level (0 hari, 10 hari, 20 hari). dan metode pemasakan yang terdiri 2 level (pengukusan dan perebusan). Hasil penelitian akan dianalisis dengan ANOVA dilanjutkan uji BNT dan DMRT $5 \%$. Perlakuan terbaik secara kimia dan fisik dengan metode Zeleny pada perlakuan penyimpanan labu kuning 0 hari dan metode pemasakan pengukusan dengan kadar air $(87.51 \%)$, total gula $(5.83 \%)$, kadar abu $(0.63 \%)$, serat kasar $(7.18 \%)$, total karotenoid $(30.0$ $\mu \mathrm{g} / \mathrm{g}$ ), total fenol (24.27 mg/g GAE), tekstur (10.69 N), kecerahan (59.54), kemerahan (5.07), dan kekuningan (27.74).
\end{abstract}

Kata kunci: Labu kuning, Lama Penyimpanan, Metode Pemasakan

\section{ABSTRACT}

The size of pumpkin (Cucurbita moschata) causes on obstacle in the use of pumpkin in household scale, because it can not be processed at once. Incorrect cooking process can change the characteristic of the pumpkin. The aim of this research is to know the change of physical and chemical characteristic on different cooking methods after storage. This research used randomized block with two factors, the storage time (0 days, 10 days, 20 days) and the cooking method (steaming and boiling). The data obtained from the research was analyzed by ANOVA and then using LSD or 5\% DMRT test. The best treatmen was done by used Zeleny method in pumpkin with 0 day storage time and steaming method with water content $(87.51 \%)$, total sugar (5.83\%), ash content (0.63\%), crude fiber $(7.18 \%)$, total carotenoid $(30.01 \mu \mathrm{g} / \mathrm{g})$, total phenol (24.27 mg/g GAE), texture (10.69 N), brightness (59.54), redness (5.07), and yellowish (27.74).

Keywords: Cooking Method, Pumpkin, Storage time

\section{PENDAHULUAN}

Labu kuning atau waluh merupakan tanaman yang termasuk dalam famili cucurbitaceae dan banyak ditemukan di semua wilayah di Indonesia. Labu kuning termasuk komoditas pangan lokal jenis sayuran yang dapat tumbuh pada dataran rendah sampai tinggi, antara 0-1500 mdpl (Hendrasty, 2003). Menurut data BPS (2014), produksi labu kuning pada tahun 2014 di Indonesia sebesar 523.063 ton. Sedangkan rata-rata tingkat konsumsi labu kuning sebesar $5 \mathrm{~kg} / \mathrm{tahun}$ (Hayati, 2006). Ukuran labu kuning yang besar tersebut 
menyebabkan kendala dalam pemanfaatan pada skala rumah tangga karena tidak bisa diolah sekaligus, sehingga seringkali masyarakat yang mengonsumsi labu kuning menyimpan labu kuning yang belum terpakai (potongan) dalam lemari pendingin $\left(3 \pm 1^{\circ} \mathrm{C}\right)$. Metode pemasakan yang paling sering digunakan untuk memasak labu kuning dalam skala rumah tangga yaitu direbus dan dikukus. Pemasakan merupakan proses termal dengan tujuan utama untuk meningkatkan citarasa produk pangan (Estiasih dan Ahmadi, 2009). Olahan labu kuning dalam masakan jepang memakai metode pengukusan untuk menjaga kandungan gizi makanan (Cassandra, 2015) serta cita rasa yang alami (Bunga, 2017). Pengukusan memiliki kelebihan dapat meminimalkan kerusakan akibat proses termal dan kehilangan komponen bahan pangan akibat proses pelarutan dapat dihindari. Proses pemasakan yang tidak tepat dapat menurunkan nilai gizi dari labu kuning tersebut, seperti kandungan mineral dan vitamin sebesar 40\%, gula 35\%, 20\% protein, dan asam amino (Estiasih dan Ahmadi, 2009). Oleh karena itu, penelitian ini dilakukan untuk memperoleh informasi pengaruh penyimpanan labu kuning potong dan metode pemasakan terhadap karakteristik labu kuning.

\section{BAHAN DAN METODE}

\section{Bahan}

Bahan yang digunakan yaitu labu kuning varietas bokor yang berbentuk pipih, warna dan ukuran sama yang diperoleh dari Pasar Besar Malang dengan penjual yang sama. Labu kuning yang digunakan memiliki karakteristik kulit yang berwarna kuning dengan sedikit warna kehijauan. Tekstur labu kuning yang digunakan $150 \pm 10 \mathrm{~N}$, berdiameter $20 \pm 2 \mathrm{~cm}$ dengan berat $2 \pm 0,3 \mathrm{~kg}$, dan tingkat kematangan mengkal. Bahan untuk analisis antara lain petroleum eter, $\mathrm{Na}_{2} \mathrm{SO}_{4}$, reagen folin ciocalteau, $\mathrm{Na}_{2} \mathrm{CO}_{3}$, aquades, etanol, asam galat, $\mathrm{HCl} 25 \%, \mathrm{NaOH} 45 \%$, $\mathrm{H}_{2} \mathrm{SO}_{4}$, Nelson $\mathrm{A}$ dan $\mathrm{B}$, Anthrone, $\mathrm{K}_{2} \mathrm{SO}_{4} 10 \%$, aseton.

\section{Alat}

Alat yang digunakan yaitu refrigerator (Electrolux), plastik pp (Petroleum), timbangan analitik (Denver Instrument), termometer, kompor (Rinnai), color reader (Konica Minota), oven (Wtb. Binder), tabung reaksi (Iwaki), centrifuge, spektrofotometer UV-Vis (20 D-Plus), vortex (Lw. Scientific), texture analyzer atau tensile strength (Imada), kompor listrik (Maspion), corong pemisah, labu ukur $100 \mathrm{ml}$ (Iwaki), erlenmeyer $500 \mathrm{ml}$ (Schott Duran), pipet volume (Pricicolor HBG).

\section{Desain Penelitian}

Penelitian ini menggunakan metode analisis Analysis of Variance (ANOVA). Apabila terdapat perbedaan dan interaksi maka dilanjutkan dengan uji Duncan's Multiple Range Test (DMRT) dengan taraf nyata $(\alpha=5 \%)$. Namun apabila dari hasil uji terdapat perbedaan dan tidak ada interaksi maka dilanjutkan dengan uji Beda Nyata Terkecil (BNT) dengan taraf nyata $(\alpha=5 \%)$. Selanjutnya dilakukan pemilihan terbaik ditentukan dengan metode Multiple Objective Decision Making (MODM) (Zeleny, 1982).

\section{Tahapan Penelitian}

Penelitian Pendahuluan

Penelitian pendahuluan dilakukan untuk menentukan lama penyimpanan labu kuning. Batas penyimpanan labu kuning ditentukan sebelum labu kuning yang disimpan ditumbuhi oleh jamur, sehingga dilakukan pengecekan setiap 7 hari. Pada hari ke-21 labu kuning yang disimpan mulai ditumbuhi jamur dengan ciri-ciri terdapat titik-titik putih yang diindikasikan sebaga jamur, sehingga dalam penelitian ini, labu kuning dilakukan penyimpanan selama 20 hari.

Pelaksanaan Penelitian

Labu kuning disortasi secara manual (berat dan warna yang sama), kemudian dipotong berbentuk melengkung seperti bulan sabit (panjang $11 \pm 2 \mathrm{~cm}$ ). Labu kuning yang sudah dipotong dimasukkan ke dalam plastik pp, kemudian disimpan pada suhu $3 \pm 1^{\circ} \mathrm{C}$ 
selama 0 hari, 10 hari dan 20 hari. Kemudian dilakukan pemasakan dengan metode pengukusan dan perebusan. Selanjutnya dilakukan analisis.

\section{Prosedur Analisis}

Analisis penelitian ini meliputi kadar air (Sudarmadji dkk, 2010), kadar abu (Sudarmadji dkk, 2010), kadar serat kasar (Sudarmadji dkk, 2010), total gula (Apriyanto, 1994), total karoteoid (Marhaeni, 2009), total fenol (Turkmen et al, 2005), warna (Yuwono, 1998), tekstur dengan tensile strength, dan uji perlakuan terbaik (Zeleny, 1982).

\section{HASIL DAN PEMBAHASAN}

\section{Karakteristik Bahan Baku}

Data karakteristik bahan baku labu kuning dibandingkan dengan pustaka dapat dilihat pada Tabel 1

Tabel 1 Karakteristik Bahan Baku Labu Kuning dengan dibandingkan dengan Pustaka

\begin{tabular}{|c|c|c|}
\hline Parameter & Labu Kuning * & Labu Kuning *夫 \\
\hline Kadar Air (\%) & $88.97^{a}$ & 89.22 \\
\hline Kadar Abu (\%) & $0.63^{a}$ & 0.57 \\
\hline Kadar Serat Kasar (\%) & $1.15^{\mathrm{a}}$ & 8.33 \\
\hline Kadar Pati (\%) & $1.41^{\mathrm{a}}$ & 3.86 \\
\hline Kadar Total Gula (\%) & $3.29^{a}$ & 5.18 \\
\hline Total Karotenoid $(\mu \mathrm{g} / \mathrm{g})$ & $21.20^{\mathrm{b}}$ & 33.68 \\
\hline Total Fenol (mg/g GAE) & $27.13^{b}$ & 28.78 \\
\hline \multicolumn{3}{|l|}{ Warna } \\
\hline Kecerahan (L) & - & 63.69 \\
\hline Kemerahan $\left(a^{*}\right)$ & - & 13.83 \\
\hline Kekuningan $\left(b^{*}\right)$ & - & 43.37 \\
\hline
\end{tabular}

Berdasarkan Tabel 1 dapat diketahui bahwa adanya perbedaan data dari hasil analisis dengan pustaka. Hal tersebut dimungkinkan karena perbedaan umur buah, keadaan iklim, tempat tumbuh, cara pemeliharaan dan pemanenan buah, dan penyimpanan buah pasca panen (Khurniyati, 2015).

\section{Karakteristik Kimia Labu Kuning}

a. Kadar air

Hasil analisis ragam menunjukkan lama penyimpanan labu kuning dan metode pemasakan labu kuning memiliki pengaruh nyata $(\alpha=0,05)$ terhadap kadar air labu kuning. Interaksi antara kedua faktor tidak memberikan pengaruh nyata $(\alpha=0,05)$ terhadap kadar air labu kuning. Pengaruh lama penyimpanan dan metode pemasakan terhadap perubahan kadar air labu kuning dapat dilihat pada Gambar 1.

Kadar air labu kuning cenderung meningkat dengan semakin lama penyimpanan. Hal tersebut disebabkan adanya bahan pengemas yang menyebabkan udara sekitar tidak mudah masuk kedalam bahan sehingga penurunan kadar air dapat diminimalisir (Naomi, 2009). Namun, apabila kemasan yang digunakan kurang vakum (masih ada udara di dalam kemasan). Udara yang jenuh dalam kemasan kemudian mengalami kondensasi (berubah menjadi uap air) dan menempel pada kemasan. Uap air yang jenuh tersebut kemudian jatuh kedalam bahan dan mengakibatkan perubahan kadar air (Negari, 2011).

Metode pemasakan dengan perebusan memiliki kadar air yang lebih tinggi. Hal tersebut disebabkan pada proses perebusan menggunakan media air panas sehingga kontak dan penetrasi panas terhadap labu kuning lebih besar pada proses perebusan dibandingkan 
dengan media pada proses pengukusan. Air panas sebagai media panas akan memberikan panas yang membuat struktur jaringan pada bahan menjadi mengembang dan berpori.

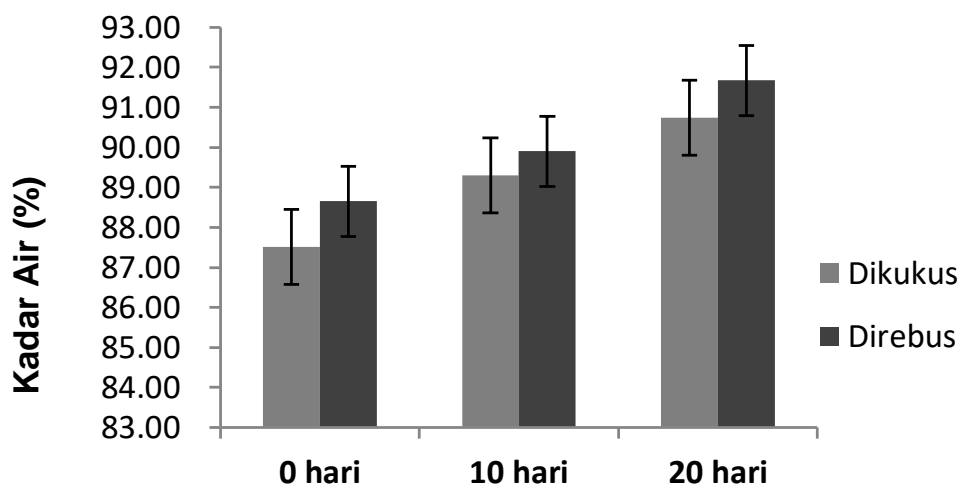

\section{Lama Penyimpanan}

Gambar 1. Pengaruh Lama Penyimpanan dan Metode Pemasakan terhadap Kadar Air Labu Kuning

\section{b. Total Gula}

Hasil analisis ragam menunjukkan bahwa lama penyimpanan labu kuning memberikan pengaruh nyata $(\alpha=0.05)$ terhadap kadar total gula, sedangkan metode pemasakan tidak memberikan pengaruh nyata terhadap $(\alpha=0,05)$ kadar total gula labu kuning serta tidak terjadi interaksi antara kedua faktor. Pengaruh lama penyimpanan dan metode pemasakan terhadap perubahan total gula labu kuning dapat dilihat pada Gambar 2.

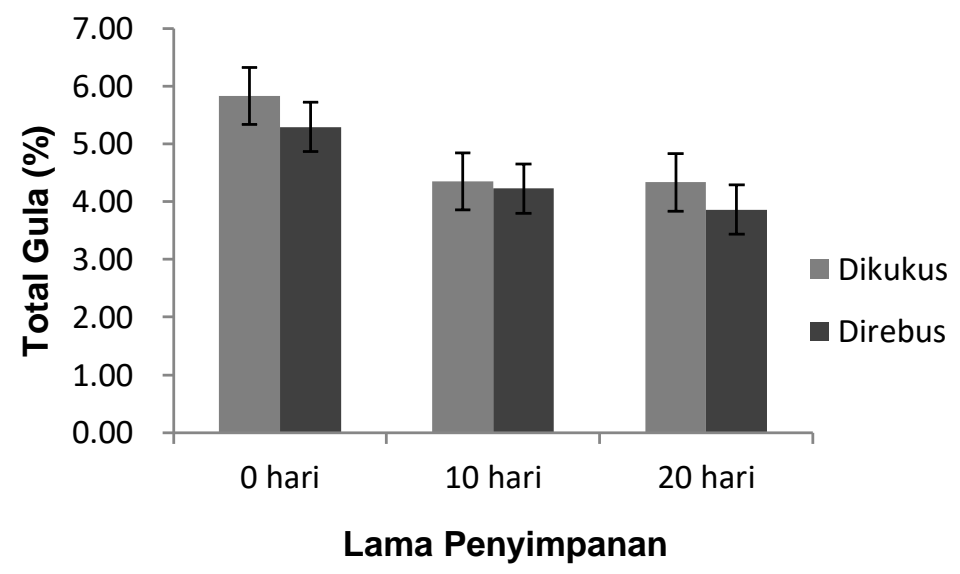

Gambar 2. Pengaruh Lama Penyimpanan dan Metode Pemasakan terhadap Total Gula Labu Kuning

Penurunan total gula selama penyimpanan disebabkan total gula hasil hidrolisa pati langsung digunakan proses respirasi lagi menghasilkan asam organik. Gula sederhana sudah memasuki tahap siklus Kreb's dimana hasil g likolisis dirubah menjadi asam-asam organik dan menghasilkan ATP, $\mathrm{CO}_{2}$, dan $\mathrm{H}_{2} \mathrm{O}$ (Purwanto dan Nur, 2015). Selain itu, penurunan gula juga dikarenakan buah yang disimpan mulai melewati masa pemasakan, dimana tahap ini kadar pati (polisakarida) sudah mulai sedikit dan aktivitas enzim menurun sehingga kadar gula menjadi turun (Saputra, 2006). Sementara itu metode pemasakan tidak berpengaruh terhadap total gula labu kuning. Hal tersebut diduga pada saat labu kuning dipanaskan, panas yang diterima oleh bahan tidak merata, sehingga kadar gula tidak dapat larut sempurna ke dalam media panas. 


\section{c. Kadar Abu}

Hasil analisis ragam menunjukkan bahwa lama penyimpanan labu kuning tidak berpengaruh nyata $(\alpha=0.05)$ terhadap kadar abu labu kuning, sedangkan metode pemasakan berpengaruh nyata $(\alpha=0.05)$ terhadap kadar abu labu kuning serta tidak terjadi interaksi antara kedua faktor. Pengaruh lama penyimpanan dan metode pemasakan terhadap perubahan kadar abu labu kuning dapat dilihat pada Gambar 3.

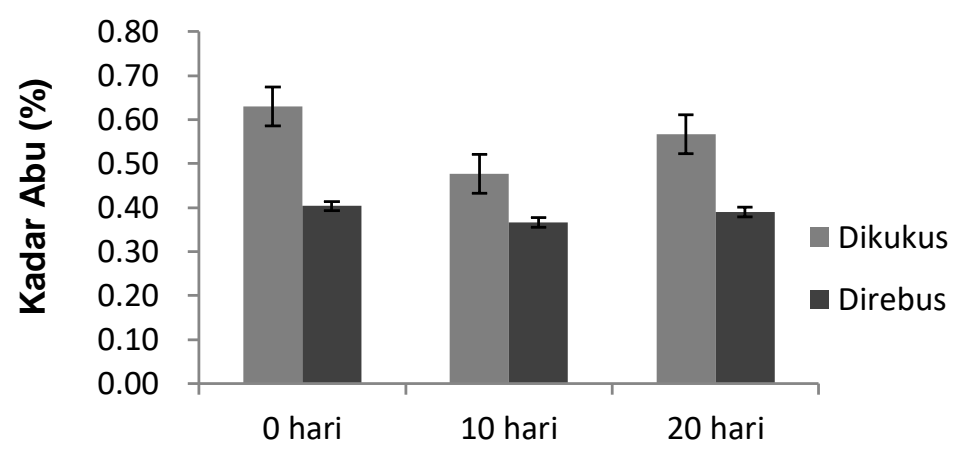

\section{Lama Penyimpanan}

Gambar 3. Pengaruh Lama Penyimpanan dan Metode Pemasakan terhadap Kadar Abu Labu Kuning

Penurunan kadar abu selama pemasakan disebabkan karena kadar abu pada labu kuning lebih banyak terlarut dalam media perebusan yang berupa air panas dibandingkan dengan media pengukusan yang berupa uap air panas. Sementara itu lama penyimpanan labu kuning tidak berpengaruh nyata terhadap kadar abu. Hal tersebut disebabkan kadar abu merupakan komponen non organik pada suatu bahan yang tersusun atas mineral-mineral (Ambarsari, 2009). Mineral yang terkandung dalam bahan pangan umumnya akan rusak pada proses pengolahan karena sensitif terhadap $\mathrm{pH}$, oksigen, sinar dan panas atau kombinasi diantaranya (Dosomu et al., 2009).

\section{d. Kadar Serat Kasar}

Hasil analisis ragam menunjukkan bahwa lama penyimpanan dan metode pemasakan tidak memberikan pengaruh nyata $(\alpha=0,05)$ serta kedua faktor tidak terjadi interaksi. Pengaruh lama penyimpanan dan metode pemasakan terhadap perubahan kadar serat kasar labu kuning dapat dilihat pada Gambar 4.

Kadar serat kasar labu kuning cenderung meningkat dengan semakin lama penyimpanan labu kuning dan metode pemasakan yang berbeda. Hal ini diduga serat kasar susah untuk diuraikan. Menurut Winarno (2008), selulosa dan hemiselulosa lebih sukar untuk diuraikan dan mempunyai sifat-sifat sebagai berikut, yaitu memberi bentuk atau struktur pada tanaman, tidak larut dalam air dingin maupun air panas, tidak dapat dicerna oleh cairan pencernaan manusia sehingga tidak dapat menghasilkan energi, dapat membantu melancarkan pencernaan makanan, dan dapat dipecah menjadi satuan-satuan glukosa oleh enzim dan mikroba tertentu. 


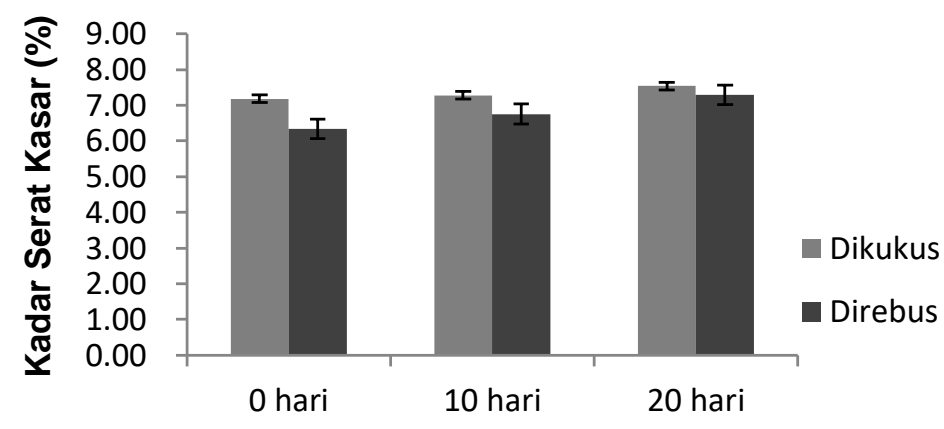

Lama Penyimpanan

Gambar 4. Pengaruh Lama Penyimpanan dan Metode Pemasakan terhadap Kadar Serat Kasar

\section{e. Total Karotenoid}

Hasil analisis ragam menunjukkan bahwa lama penyimpanan dan metode pemasakan labu kuning memberikan pengaruh nyata $(\alpha=0.05)$ terhadap kadar total karotenoid serta terjadi interaksi antara kedua faktor. Pengaruh lama penyimpanan dan metode pemasakan terhadap perubahan total karotenoid labu kuning dapat dilihat pada Gambar 5.

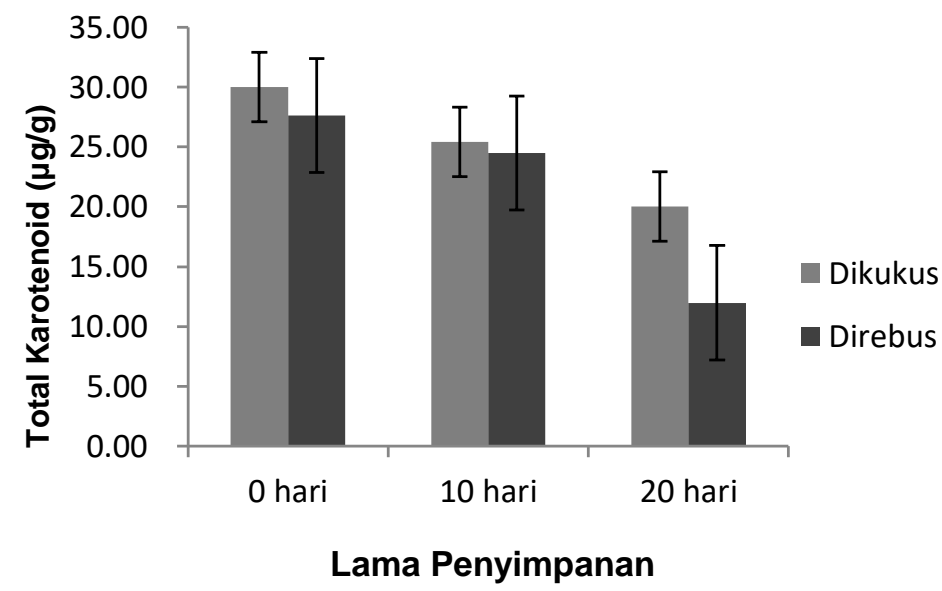

Gambar 5. Pengaruh Lama Penyimpanan dan Metode Pemasakan terhadap Total Karotenoid Lanu Kuning

Pada proses pemasakan perebusan dang pengukusan menggunakan suhu yang tinggi, sehingga jaringan kromoplas yang terdapat dalam sitoplasma buah mengalami kerusakan. Akibatnya karotenoid didalamnya keluar dari dalam sel sehingga kadar total karotenoid mengalami penurunan. Selain itu, labu kuning metode pemasakan perebusan memiliki kadar karotenoid lebih rendah dibandingkan dengan labu kuning metode pemasakan pengukusan yang disebabkan pada proses perebusan, karotenoid yang telah keluar akibat kerusakan kromoplas tersebut lebih larut dalam dalam media air panas dari pada uap air.

Labu kuning selama penyimpanan dikemas menggunakan plastik pp dengan tidak terlalu rapat, sehingga didalam kemasan masih ada kandungan oksigen. Adanya oksigen memicu proses oksidasi non enzimatik, dimana terjadi degradasi betakaroten sehingga menyebabkan ikatan konjugasi rusak dan mengakibatkan warna lebih pucat (Rodriguez dan Kimura, 2009). Selain itu, penurunan total karotenoid labu kuning juga diakibatkan adanya cahaya yang menyebabkan molekul karotenoid terdegradasi lebih cepat akibat putusnya 
ikatan rangkap pada struktur karotenoid sehingga struktur dan sifat-sifat karotenoid menjadi berubah (Button et al., 2008).

\section{f. Total Fenol}

Hasil analisis ragam menunjukkan bahwa lama penyimpanan dan metode pemasakan memberikan pengaruh nyata $(\alpha=0,05)$ terhadap total fenol labu kuning serta tidak terjadi interaksi antara kedua faktor. Pengaruh lama penyimpanan dan metode pemasakan terhadap perubahan total fenol labu kuning dapat dilihat pada Gambar 6.

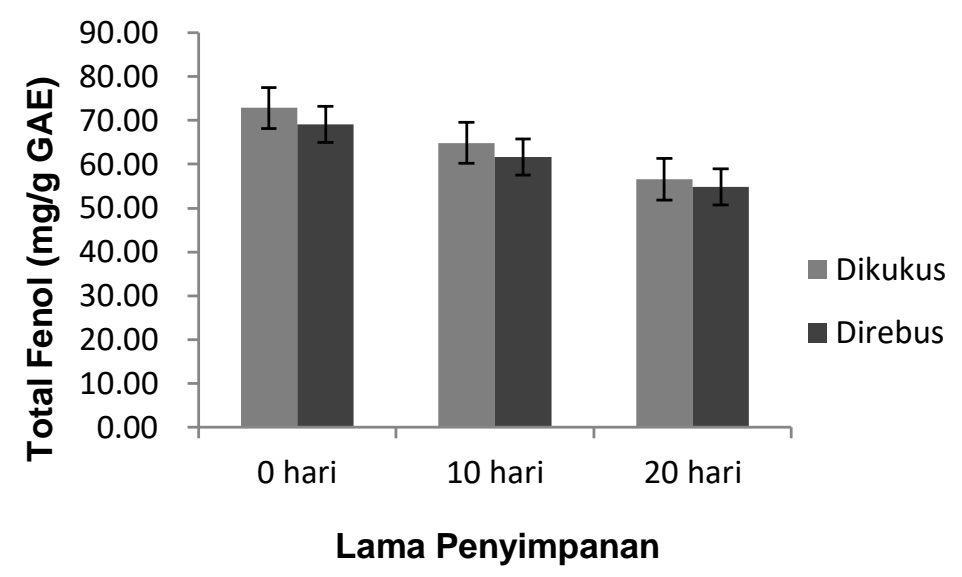

Gambar 6. Pengaruh Lama Penyimpanan dan Metode Pemasakan terhadap Total Fenol Labu Kuning

Penurunan kadar total fenol selama penyimpanan diduga karena adanya proses oksidasi ataupun secara enzimatis akibat proses pelukaan. Adanya luka menginduksi sintesis enzim PAL (Phenilalanin Ammonia Liase) dalam metabolisme fenolik yang berfungsi meningkatkan produksi komponen dan pencoklatan (Murdijati dan Yuliana, 2014). Menurut Chilaka et al. (2002) penurunan kandungan total fenol disebabkan terjadinya oksidasi senyawa fenolik oleh udara atau karena aktifitas enzim polyphenol oksidase (PPO) di dalam bahan. Oksidasi senyawa fenolik oleh PPO pada produk nabati menyebabkan perubahan warna produk menjadi kecoklatan (Wisnu dkk, 2015).

Metode pemasakan pengukusan memiliki total fenol yang lebih tinggi daripada perebusan. Hal tersebut disebabkan air panas sebagai media panas akan merusak dinding sel dan membran plasma, sehingga air panas masuk kedalam dinding sel dan vakuola yang kemudian melarutkan senyawa fenol kedalam cairan pengolahan (Aisyah dkk, 2015).

\section{Karakteristik Fisik Labu Kuning}

Karakteristik fisik yang dianalisis meliputi tekstur, kecerahan (L), kemerahan (a), serta kekuningan (b). Rerata tekstur labu kuning setelah perlakuan penyimpanan dan pemasakan berkisar antara 8,63-10,69 N. Pengaruh lama penyimpanan dan metode pemasakan terhadap perubahan tekstur labu kuning dapat dilihat pada Tabel 2.

Tabel 2. Pengaruh Lama Penyimpanan dan Metode Pemasakan terhadap Perubahan

\begin{tabular}{ccc} 
& Tekstur Labu Kuning \\
\hline Lama Penyimpanan (hari) & Nilai Tekstur (N) & BNT 5\% \\
\hline 0 & $11.02 \mathrm{~b}$ \\
10 & $9.80 \mathrm{ab}$ & 1.22 \\
20 & $8.79 \mathrm{a}$ & \\
\hline
\end{tabular}

Selama penyimpanan labu kuning, proses respirasi masih terjadi sehingga menyebabkan proses pematangan yang dikaitkan dengan pelunakan dengan ditandai perubahan dinding sel. Menurut Gonzalves dkk (2005) melaporkan bahwa pelunakan jaringan 
pada saat pemasakan dan penyimpanan pada kultivar $C$. maxima dan $C$. moschata disebabkan oleh pelarutan total pektin, sehingga mengakibatkan menurunnya adhesi sel, ketebalan dinding sel sehingga mempengaruhi perubahan tekstur. Perubahan secara kimiawi juga terjadi pada dinding sel yang tersusun dari senyawa kompleks dari golongan karbohidrat struktural, seperti selulosa, hemiselulosa, pektin dan lignin (Widjanarko, 2012).

Hasil analisis tingkat kecerahan labu kuning berkisar antara 59,54-65,51. Pengaruh lama penyimpanan dan metode pemasakan terhadap perubahan nilai kecerahan labu kuning dapat dilihat pada Tabel 3.

Tabel 3. Pengaruh Lama Penyimpanan dan Metode Pemasakan terhadap Perubahan Kecerahan Labu Kuning

\begin{tabular}{cccc}
\hline Lama Penyimpanan (hari) & Metode Pemasakan & Kecerahan & DMRT 5\% \\
\hline 0 & Kukus & $59.54 \mathrm{ab}$ & 1.257 \\
& Rebus & $59.32 \mathrm{a}$ & 1.202 \\
10 & Kukus & $61.07 \mathrm{~b}$ & 1.288 \\
& Rebus & $61.41 \mathrm{c}$ & 1.309 \\
20 & Kukus & $63.55 \mathrm{~d}$ & 1.322 \\
& Rebus & $65.51 \mathrm{e}$ & \\
\hline
\end{tabular}

Perubahan nilai kecerahan yang semakin meningkat menunjukkan labu kuning yang semakin cerah. Perubahan warna pada labu kuning berhubungan dengan total karotenoidnya. Perubahan kecerahan yang menjadi semakin cerah disebabkan oleh proses oksidasi karoten secara non enzimatik selama penyimpanan, dimana terjadi degradasi betakaroten sehingga menyebabkan ikatan konjugasi rusak dan mengakibatkan warna lebih pucat (Rodriguez dan Kimura, 2009).

Perbedaan metode pemasakan, labu kuning metode pengukusan memiliki warna yang lebih gelap daripada metode perebusan. Hal tersebut disebabkan pengukusan memiliki jenis transfer panas berupa uap panas, yang dapat memicu timbulnya oksidasi fenol. Adanya panas dan oksigen mengakibatkan senyawa total fenol pada bahan teroksidasi dalam larutan alkali atau karena aktifitas enzim polifenol okidase yang membentuk radikal orti-semiquinomn yang bersifat reaktif dan dapat bereaksi lebih lanjut dengan senyawa amino membentuk produk berwarna coklat (Aisyah dkk, 2015).

Adanya korelasi negatif menunjukkan bahwa semakin menurun total karotenoid maka nilai kecerahan juga akan semakin tinggi. Korelasi antara nilai kecerahan dengan total karotenoid dapat dilihat pada Gambar 7.

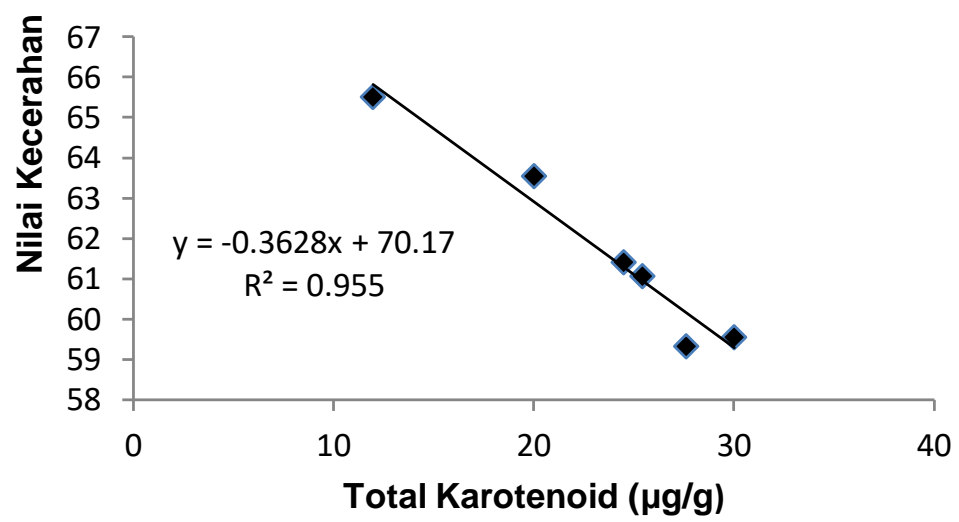

Gambar 7. Grafik Korelasi antara Nilai Kecerahan dan Total Karotenoid Labu Kuning 
Hasil analisis tingkat kemerahan $\left(\mathrm{a}^{*}\right)$ labu kuning berkisar antara 2.75-5.07. Pengaruh lama penyimpanan dan metode pemasakan terhadap perubahan nilai kemerahan labu kuning dapat dilihat pada Tabel 4.

Tabel 4. Pengaruh Lama Penyimpanan dan Metode Pemasakan terhadap Perubahan Kemerahan Labu Kuning

\begin{tabular}{ccc}
\hline Lama Penyimpanan (hari) & Kemerahan $\left(\mathbf{a}^{*}\right)$ & BNT 5\% \\
\hline 0 & $4.79 \mathrm{c}$ & \\
10 & $3.78 \mathrm{~b}$ & 0.62 \\
20 & $2.80 \mathrm{a}$ & \\
\hline
\end{tabular}

Nilai kemerahan mengalami penurunan yang disebabkan pelukaan pada buah yang dapat menginduksi sintesis enzim PAL (Phenilalanin Ammonia Liase) dalam metabolisme fenolik yang berfungsi meningkatkan produksi komponen dan pencoklatan (Murdijati dan Yuliana, 2014). Selama penyimpanan, kandungan fenol mengalami penurunan akibat teroksidasi sehingga nilai kemerahan juga mengalami penurunan akibat enzim PPO yang mengkatalis oksidasi fenol tidak dapat bekerja karena menurunnya ketersediaan fenol.

Sementara itu perlakuan metode pemasakan yang berbeda memberikan pengaruh tidak nyata terhadap nilai kemerahan labu kuning. Nilai kemerahan menunjukkan warna labu kuning yang cenderung gelap, yang dipengaruhi oleh adanya kandungan gula. Gula yang dipanaskan terus hingga suhunya melampaui titik leburnya akan terjadi proses karamelisasi. Pembentukan caramel ini membantu mempertajam warna dan menghasilkan warna yang kecoklatan (gelap) (Winarno, 2002). Namun, suhu yang digunakan selama pemasakan kurang stabil sehingga proses karamelisasi tidak terjadi secara maksimal.

Hasil analisis nilai kekuningan ( $\left.b^{*}\right)$ labu kuning berkisar antara 27.74-33.45. Pengaruh lama penyimpanan dan metode pemasakan terhadap perubahan nilai kekuningan labu kuning dapat dilihat pada Tabel 5.

Tabel 5. Pengaruh Lama Penyimpanan dan Metode Pemasakan terhadap Perubahan Kekuningan Labu Kuning

\begin{tabular}{ccc}
\hline Lama Penyimpanan (hari) & Kekuningan $\left(\mathbf{b}^{*}\right)$ & BNT 5\% \\
\hline 0 & $27.91 \mathrm{a}$ & \\
10 & $32.08 \mathrm{~b}$ & 1.70 \\
20 & $33.39 \mathrm{~b}$ & \\
\hline
\end{tabular}

Peningkatan nilai kekuningan labu kuning tersebut menunjukkan perubahan warna labu kuning yang semakin kuning. Adanya oksidasi non enzimatik menyebabkan degradasi betakaroten sehingga menyebabkan ikatan konjugasi rusak dan mengakibatkan warna lebih pucat (Rodriguez dan Kimura, 2009).

Sementara itu perlakuan metode pemasakan yang berbeda memberikan pengaruh tidak nyata terhadap nilai kekuningan labu kuning. Hal tersebut diduga pada saat labu kuning dipanaskan, panas yang diterima oleh bahan tidak merata, sehingga tidak berpengaruh pada perubahan nilai kekuningan.

\section{Perlakuan Terbaik}

Parameter yang digunakan pada penentuan perlakuan terbaik secara kimia dan fisik meliputi hasil kadar air, kadar pati, total gula, serat kasar, kadar abu, total karotenoid, total fenol, warna (L, a, b) dan tekstur. Berdasarkan hasil penentuan terbaik secara kimia dan fisik adalah perlakuan L1M1 (lama penyimpanan 0 hari dan metode pemasakan pengukusan). Hasil pengujian perlakuan terbaik dapat dilihat pada Tabel 6. 
Tabel 6. Karakteristik Kimia dan Fisik Labu Kuning Potong Perlakuan Terbaik

\begin{tabular}{lc}
\hline \multicolumn{1}{c}{ Parameter } & Labu Kuning Potong Perlakuan Terbaik \\
\hline Kadar Air $(\%)$ & 87.51 \\
Total Gula $(\%)$ & 5.83 \\
Kadar Surat Kasar $(\%)$ & 7.18 \\
Kadar Abu (\%) & 0.63 \\
Total Karotenoid $(\mu \mathrm{g} / \mathrm{g})$ & 30.01 \\
Total Fenol (mg/g GAE) & 24.27 \\
Warna (L) & 59.32 \\
Warna (a) & 5.07 \\
Warna (b) & 27.74 \\
Tekstur (N) & 10.69 \\
\hline
\end{tabular}

\section{SIMPULAN}

Perlakuan lama penyimpanan labu kuning potong berpengaruh nyata terhadap tekstur, warna (L, a, b), kadar air, total gula, kadar pati, total karotenoid, dan total fenol labu kuning namun tidak berpengaruh nyata terhadap kadar serat kasar dan kadar abu labu kuning. Metode pemasakan labu kuning potong berpengaruh nyata terhadap warna $(L)$, kadar air, kadar abu, kadar total karotenoid, dan total fenol labu kuning namun tidak berpengaruh nyata terhadap tekstur, warna (a, b), total gula, kadar pati, kadar serat kasar labu kuning.

Interaksi antara lama penyimpanan dan metode pemasakan labu kuning potong berpengaruh nyata terhadap kecerahan warna $(L)$ dan kadar total karotenoid labu kuning potong namun tidak berpengaruh nyata terhadap tekstur, warna $(a, b)$, kadar air, total gula, kadar abu, kadar pati, kadar serat kasar, dan total fenol labu kuning potong. Perlakuan terbaik secara kimia dan fisik pada perlakuan penyimpanan labu kuning 0 hari dengan metode pemasakan pengukusan.

\section{DAFTAR PUSTAKA}

Aisyah, Y., Rasdianshah, dan Muhaimin. 2015. Pengaruh Pemanasan terhadap Aktivitas Antioksidan pada Beberapa Jenis Sayuran. Jurnal Teknologi dan Industri Pertanian Indonesia. 6: 02, 28-32.

Ambarsari, I., Sarjana dan Choliq, A. 2009. Rekomendasi Standar Mutu Tepung Ubi Jalar. Jurnal Standarisasi 11: 3, 212-219.

Bunga, R. 2017. Kebiasaan Makan Wanita Jepang. https://food.idntimes.com. Tanggal akses: 20/12/2017.

Button, G., Liaaen-Jensen, S., and Fanden, H.P. 2008. Carotenoids: Volume 4. Binkhausen Inc. Berlin.

BPS, 2014. Data Produksi Tanaman Semusim. Jakarta.

Cassandra. 2015.2 Marinated Japanese Pumpkin. http://allrecipes.com.au/recipe/10860/marinated-japanese-pumpkin.aspx. Tanggal akses: 19/12/2017.

Dosomu, O.O., Oluwaniyi, O.O., Awolala, G.V dan Okunola, M. O. 2009. Stability Studies and Mineral Concentration of Some Nigerian Packed Fruit Juices, Concentrate and Local Beverages. African Journal of Food Science 3: 3, 82-85.

Estiasih, T dan Kgs, Ahmadi. 2009. Teknologi Pengolahan Pangan. Bumi Aksara. Jakarta.

Hayati, M.N. 2006. Pengaruh Jenis Asidulan terhadap Mutu Pure Labu Kuning (Cucurbita pepo L.) Selama Penyimpanan dan Aplikasinya dalam Pembuatan Pudding. http://repository.ipb.ac.id/handle/123456789/48590. Tanggal akses: 4/9/2016.

Hendrasty, H.K. 2003. Tepung Labu Kuning: Pembuatan dan Pemanfaatannya. Karnisius. Yogyakarta. 
Khurniyati, M. I. 2015. Pengaruh Konsentrasi Natrium Benzoat dan Kondisi Pasteurisasi (Suhu dan Waktu) terhadap Karakteristik Minuman Sari Apel Berbagai Varietas: Kajian Pustaka. Jurnal Pangan dan Agroindustri 3: 2, 523-529.

Naomi, N. 2009. Pengaruh Jenis Bahan Pengemas terhadap Kualitas Produk Cabai Merah (Capsicum annuum L.) Segar Kemasan Selama Penyimpanan Dingin. Tesis. Univesitas Sumatera Utara. Medan.

Hariadi, P. dan Aini, N. 2015. Dasar-Dasar Penanganan Pasca Panen Buah dan Sayur. Penerbit Alfabeta. Bandung.

Rodriguez, A. B. D., dan Kimura, M. 2009. Harvest Plus Handbook of Carotenoid Analysis. Campinas. Harvest Plus.

Saputra D., Syafitri, M.I., dan Pratama F. 2006. Sifat Fisik dan Kimia Buah Mangga (Mangifera indica L.) Selama Penyimpanan dengan Berbagai Metode Pengemasan. Jurnal Teknologi dan Industri Pangan, 17: 1, 1-11.

Widjanarko, S.B. 2012. Fisiologi dan Teknologi Pasca Panen. UB Press. Malang.

Winarno, F.G. 2008. Fisiologi Lepas Panen Produk Holtikultura. Penerbit Mbrio Press. Bogor.

Wisnu, L., Kawiji, dan Atmaka, W. 2015. Pengaruh Suhu dan Waktu Pasteurisasi terhadap Perubahan Kadar Total Fenol pada Wedang Uwuh Ready to Drink dan Kinetika Perubahan Kadar Total Fenol Selama Penyimpanan. Jurnal Teknologi Hasil Pertanian 6: 2, 71-76. 